\title{
Hire Purchase Strategy of Physical Capital Investment and Financial Performance of Construction Companies: Illustrating from the Nigerian Stock Exchange
}

\author{
Loveday A. Nwanyanwu, PhD, FCA, FCTI. \\ Department of Accountancy, \\ Rivers State University of Science and Technology, \\ Port Harcourt, Rivers State,, Nigeria.
}

\section{Doi:10.5901/mjss.2013.v4n4p449}

\section{Abstract}

The purpose of this paper is to identify the influence of hire purchase strategy of physical capital investment on financial performance of construction companies quoted on the Nigerian Stock Exchange. Data were obtained through questionnaire. Analyses were performed using descriptive statistics and Pearson's product moment coefficient of correlation. Empirical results indicate that there exist a statistically significant negative association between hire purchase strategy of investing in physical capital and financial performance of construction companies. It was concluded that considering the complexities in service delivery, application of hire purchase as a physical capital investment option, may not provide the quantum of capital assets needed to satisfy expectations of customers.

Keywords: Hire purchase, physical capital, financial performance, construction companies, Nigerian Stock Exchange, Nigeria.

\section{Introduction}

Physical capital constitutes a major component of the entire resources available to an organization. Its investment is essential in piloting corporate activities and for the production of goods and services. They include investment in machinery, plant, equipment, buildings, motor vehicles, furniture and fittings. In accounting literature, they are also described as "real", "tangible" or "fixed assets".

Construction companies are amongst major industry consumers of physical capital. Participants in this sector require adequate investment in physical capital to produce services that meet the demands of their customers. According to Prasertrungruang and Hadikusumo (2007, p. 228), high way construction business is a sector that relies primarily on high utilization of machinery; by utilizing machinery, an extensive volume of work can be completed in a shorter period of time and within the project schedule. Also, in the views of Day and Benjamin (1991), equipment is thus one of the key factors for improving contractors' capability in performing their work more effectively and efficiently.

In Nigeria, construction companies with insufficient investment in equipment and machinery have witnessed negative consequences including reduced profitability or outright losses, excessive debt burden arising from dependence on borrowed funds for operations; loss of manpower and threats of liquidation. Kehinde and Mosaku (2006, p. 634) in their work on an empirical study of assets structure of building construction contractors in Nigeria, reported that construction contracting firms in both the building and civil engineering sub-sectors require various types of efficiently managed assets in a different mix to successfully and profitably carry out their primary (core) operation. They noted that in a complex and highly competitive industry as the construction industry, with ever changing operating environment, the assets portfolio of any contracting firm determines how far they can go, what they can handle and what share of the market they can get. The high failure rate and low performance of contracting firms in the industry, as noted by Cannon and Hillebrandt, (1989) and Chiang et al (2002) is precipitated by the apparent low level of investment in fixed assets, which could serve as collateral for loans during times of distress.

Strategies for investing in physical capital vary depending on the nature of the item. However, as reported by Alexander and Britton (1999), investment in physical capital could be by outright (cash) purchase, credit sale agreement, hire purchase (HP) and leasing. Outright (cash) purchase involves full payment of a physical capital while credit sale agreement postpones payment of a capital item at a later date specified in the agreement; in both cases, ownership is transferred to the investor. Hire purchase on the other hand, permits acquisition of a physical capital through installmental payments; ownership is transferred on the payment of the last installment. In the case of leasing, a consumer obtains the 
services of a physical capital through rental payments; ownership may or may not be transferred at the end of the lease term. This paper, examines the hire purchase option of investing in physical capital and how it impacts on financial performance of construction companies in Nigeria.

\section{Gap in knowledge}

Some studies in the past have made attempts to investigate the investment strategy of construction companies. Strategies have often times been developed for businesses generally aimed at improving organizational performance. Recently, complexities in service delivery have prompted scholars to change this perspective by researching for strategies within the context of the construction industry considering its sensitivity in the provision of infrastructure. In this direction, Cheah and Garvin (2004, pp.176 - 188) documented a conceptual model that adopts an open methodology to resolve the varying factors of success and failure in construction and the different theories associated with strategy development. The model comprised seven strategic fields of corporate strategy: business, financial, human resources, information technology, marketing, operational and technology strategies. These fields constitute the hub of corporate strategy in construction which should be considered to create better chances for success. Tatum (1988) in another dimension, demonstrated that the range for possible technology - based strategies for construction firms is wide; pointing out that, at present, choices and means for technology development still remain the most questions in technology strategy.

The foregoing studies did not focus on the hire purchase strategy of physical capital acquisition within the construction industry. This study attempts to fill this gap by empirically examining the hire purchase strategy of physical capital investment, especially, in the Nigerian context and its impact on financial performance. The next section will feature literature review. This will be followed by statement of the problem and methodology. The last sections will consider data presentation and analysis, discussion of findings, conclusions and recommendations..

\section{Literature Review}

\subsection{Background}

Hire purchase is one of the approaches adopted for investing in physical capital. It confers on the hirer the benefits of a physical capital in return for installmental payments; ownership is transferred on the payment of the last installment. As posited by Jaja (2000), it is an increasingly important source of medium term financing for businesses used to finance the purchase of capital goods, ranging from plant and equipment to commodities and vehicles and their insurance.

The Hire Purchase Act, Cap H.4 Laws of the Federation of Nigeria (LFN), 2004 describes hire purchase as the bailment of goods in purchase of an agreement under which the bailee may buy the goods or under which the property in the goods will or may pass to the bailee. The Act further clarifies what constitutes a hire purchase price as being the total sum payable by the hirer under a hire purchase agreement in order to complete the purchase of goods to which the agreement relates, exclusive of any sum payable as a penalty or as compensation or damages for breach of the agreement but including any sum payable by the hirer under the agreement by way of deposit or other initial payment, or credited or to be credited to him under the agreement on account of any such deposit or payment, whether that sum is to be or has been paid to the owner or to any other person or is to be or has been discharged by a payment of money or by the transfer or delivery of goods or by any other means.

In Nigeria, the Hire Purchase Act of 1965 was the first enactment that regulated hire purchase transactions. It initially affected the former territory of Lagos but became applicable to all parts of the Federation in 1966 following the enactment of the Hire Purchase (Application) Act No. 42 of 1966. The Act became operational on 1st October, 1968, by the Hire- purchase Act, 1965 (Appointed day) Order, L. N 90 of 1968 (Okany, 1992).

Prior to that of Nigeria, England as stated by Okany (1992) introduced the first English Hire Purchase Act in 1938. He traced the origin of modern hire purchase agreement to the mid-Victorian custom in furnishing trade under which persons who were not sufficiently worthy of open credit were allowed to have possession, on condition that if certain arranged payments were made, the property in the goods became vested in them, after the whole of the arranged payments were duly made. According to him, the true hire purchase agreement came into lime-light when the Factors Act, 1889 introduced the rule that a buyer in possession of the goods could pass a good title to a bona fide purchaser or pledgee. This rule altered the hire purchase agreement so as to take the form of a contract of hire plus an option to purchase. Consequently, the Hire Purchase Act 1938 was repealed and replaced by the Hire Purchase Act, 1965 which provides statutory protection in many respects. 


\subsection{Features of Hire Purchase.}

From the statutory definition of hire purchase under S.20 of the Hire purchase Act, five characteristic features are identified. They are: it is a contract, it is a bailment, it involves passing of property and there is the right to determine agreement as well as the option to purchase the property (Igweike, 1999).

A hire purchase agreement is a contract between the owner of the goods and the hirer. By law, it is reduced in writing and made obligatory through the inclusion of certain statutory terms. As a contract, it must as a matter of necessity satisfy the ordinary rules regarding the creation of enforceable rights and assumption of obligations under the law of contract.

As a bailment, the relationship between the owner of the goods and the hirer is that of a bailor and bailee. With respect to the passing of property, the object of the agreement is to ensure that the property in the goods bailed or hired remains in the owner, such that the bailee or hirer will be unable to pass any title in the goods to a third party during the period of the bailment. To achieve this objective, the agreement must confer on the hirer the option to purchase or return the goods during the hire-purchase period. The absence of such a provision in the agreement renders it a mere contract to buy and sale goods under the Sale of Goods Act.

Under a hire purchase agreement the hirer is entitled to the right to determine the agreement and return the goods to the owner. At this point, the hirer is no longer obliged to make further payments except the installment due and unpaid at the time of returning the goods.

Alternatively, the agreement also entitles the hirer with the option to purchase the goods instead of returning them. This is done at the expiration of the hire purchase period and the payment of all installments due. When purchase option is effected, ownership of the goods transfers to the hirer together with all the benefits and obligations of ownership

\subsection{Hire Purchase Financing.}

Different approaches surround the financing of hire purchase transactions. From the perspective of Igweike (1999, pp.2224), they could be financed through: dealer/seller financing method, use of bills of exchange or promissory notes and mortgage financing method. Adopting the dealer/seller financing method, the dealer/seller of the goods finances them himself and lets them to the hirer. A triangular financing method may be applied where the dealer is unable to finance the transaction. This approach leads to a dealer introducing the hirer to an investor (usually a finance company) who if satisfied with the credit worthiness of the hirer, enters into a hire purchase agreement for the cash price of the goods and a hire purchase charge.

The use of promissory notes to finance hire purchase transactions may be resorted to especially, where the goods involved may be of high value. In respect of this scenario, the hirer obtains possession of the goods upon the issuance of a promissory note to the dealer accepting to pay agreed hire purchase price by installments as contained in the agreement. The dealer will then endorse the note to a finance company or discount it with a Bank in return for a payment representing an amount agreed to be advanced by the company.

The mortgaging of hire purchase agreements as a financing method is popular in developed countries such as the United Kingdom than in Nigeria. Under this method, the dealer instead of outright sale of his hire purchase agreement, he may mortgage either his right of property in the goods or his contractual rights under the agreement to a finance company. The mortgage may be a legal mortgage which usually takes the form of an assignment in favour of the finance company with a provision for re-assignment or redemption. It may also be an equitable mortgage which is usually affected by an intention to assign, which assignment has not been perfected. Both types of mortgages can be created orally or in writing.

In addition to these financing methods is the block discounting/hire purchase stocking and mortgage agreements suggested by Goode in Igweike (1999). This approach permits the dealer to assign to the finance company his rights under blocks of hire - purchase agreements at stated intervals.

Normally, the finance company takes over these hire purchase agreements from the dealer at a discount while the dealer is made responsible for collecting the installments from the hirer as agent for the finance company. Usually, the finance company acquires ownership of the dealer's stock of goods which it then lends out on hire purchase to the dealer. The dealer is, however, granted authority to sell or let them out on hire purchase to his own customers. This method has legal complexities and as a result, stocking agreements have lost their popularity with finance companies.

\subsection{Obligations of the Parties to Hire Purchase Agreement.}

Hire purchase agreement confers certain obligations to the parties involved, namely: the owner, hirer and dealer (Okany, 
1992 and Achike, 1985). The owner is obliged to deliver to the hirer, the goods which are the subject matter of the hirepurchase agreement; posses a good title to the goods, avoid interference with the hirer's enjoyment of the goods and ensure that the goods are fit for the purpose for which they were hired.

Similarly, the hirer is expected to accept delivery of the goods which are the subject matter of the hire purchase agreement, to pay punctually the various sums provided for in the hire purchase agreement, to use the goods for the purpose for which they were hired and to re-deliver the goods to the owner in the event of termination of the hire purchase agreement.

The obligations of the dealer in a hire purchase transaction sometimes create an ambiguous situation. Where the dealer is owner of the goods by reason of financing them, he is responsible for the description, quality and fitness of the goods. But if the dealer is not the financier, his duty is just to introduce the hirer to the finance company, he assumes no contractual obligation and if agency relationship is to develop between them, it should be through agreement, in which case the functions of the dealer would be spelt out in the terms of the contract.

\subsection{Accounting for Hire Purchase Transactions.}

Accounting for hire-purchase transactions takes different dimensions in the books of the hirer and the owner. In the book of the hirer, capital assets under hire-purchase are recorded as assets at their "cash prices" with an equivalent amount being recognized in the account of the owner as a liability. Associated depreciations at appropriate rates applied on the cash price are written off to the profit and loss account together with the interest charge forming part of the total hirepurchase price. Installments paid are debited to the owners account and credited to Bank account. This aspect extinguishes the liability of the hirer to the owner until the end of the hire-purchase agreement when ownership passes to the hirer.

While in the books of the owner, the cash price aspect of the total hire-purchase amount is debited to the hirepurchaser's account and credited to the hire-purchase sales account. Installmental payments received are credited to the hire-purchaser's account to reduce the indebtedness of the hirer and debited to the bank account. At the end of the period, the interest income portion of the installment received together with the total amount in the hire-purchase sales accounts are transferred to the profit and loss account. The accounting procedures described confirm that hire-purchase arrangement is a practice of investing in physical capital assets by a company (the hirer).

\subsection{Advantages of Hire Purchase.}

Some advantages surround the use of hire-purchase arrangement as a practice of investing in physical capital. The system allows credit to someone who is unable to pay cash for the goods he wants and who would be happy to pay some deposit and thereafter pay the balance installmentally at a stipulated rate of interest. The system has become an instrument of economic policy, since it encourages people to demand more goods. It has also been used by government as an effective instrument for the restriction or stimulation of public demand for goods, depending on whether the government wants to stop inflation or cure depression and it facilitates the provision of credit to a dealer or manufacturer of goods to enable him continue in business (Adesany and Oloyede 1983).

\subsection{Disadvantages of Hire Purchase.}

The disadvantages include: the equipment under hire may soon after exercise of option to purchase become technologically obsolete; where the equipments are unfit for the purposes for which they were hired, frequent breakdowns may lead to losses, poor cash flow projections may delay installmental payments and subsequently frustrate the planned investment decision and where the arrangements are engulfed by litigations, payment of damages may outweigh the cost of outright purchase. Empirical studies show that hire-purchase arrangement as a practice of investing in physical capital assets is of limited application. A field study for economic use of plant and equipment rated hire-purchase 5.9 percent (Kehinde and Mosaku, 2006 p. 639).

The next section will discuss financial performance which is the dependent variable together with its measures: net profit (NP), return on assets (ROA) and return on equity (ROE).

\subsection{Financial Performance.}

Financial performance is one of the most important areas of measurement. Fortunately it is also one of the most objective 
measures of a firm's overall performance. Accounting related measures have the advantage of being comparable both to industry norms and to historical performance. The most common and simplest measure of financial performance is net profit or net income (Fry et al, 1998). Relatively, financial ratios are commonly used measures for evaluating financial performance (Libby et al, 2001; Dyckman et al, 1998, Pandey 1979 and Hicks and Gullett 1981). This paper measured financial performance in terms of net profit (NP), return on assets (ROA) and return on equity (ROE).

\subsection{Net Profit (NP)}

Profit is the excess of total income over total expenses during a given period of time. Total expenses in this definition refer to revenue or recurrent expenses consumed in generating the incomes. Harvey and Keer (1978) contend that accounting profit is defined as revenues minus expenses. Revenue is increases in the assets of the business which result from sale of either stock in trade or the services that the business is in existence to provide. The expenses matched with revenues in the determination of accounting profit are those reductions in the value of asset incurred in generating the revenues. Profit is the ultimate output of a company and it will have no future if it fails to make sufficient profits.

\subsection{Return on Assets (ROA)}

The Return on assets ratio, evaluates financial performance of a company in terms of its investment in total assets. The formular for calculating it is:

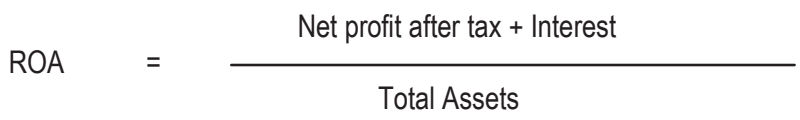

The total assets have been financed from funds supplied by creditors and owners. In measuring the return on assets, the intension is to judge the effectiveness in using the total funds supplied. The return on asset is a useful measure of the profitability of all financial resources invested in the firm's assets. It evaluates the use of total funds without any regard to the sources of funds (Pandey 1979).

Many analysts consider the return on total assets ratio to be a better measure of management's ability to effectively utilize assets independent of how the assets were financed. Under the return on assets, (also called return on total investment ratio), investment is the amount of resources provided by both owners and creditors (Libby et al, 2001).

\subsection{Return on Equity (ROE)}

Return on equity is the ratio of net profit after taxes to ordinary shareholders' equity. Return on equity is a fundamental test of profitability. It relates income earned to the investment that was made by the owners. It reflects the simple fact that investors expect to earn more money if they invest more money. It provides the most comprehensive framework for evaluating company performance. Managers, analysts, and creditors use this ratio to assess the effectiveness of the company's overall business strategy - it's operating, investing and financing strategies (Libby et al, 2001). Mathematically, return on equity is expressed thus:

ROE $=\frac{\text { Net profit after tax }- \text { Preference Dividend }}{\text { Shareholders Equity }}$

\section{Statement of the problem}

From the body of knowledge, ability to satisfy consumers' expectations by construction contractors depends on the level of investment in physical capital. Inadequate investment results into low profitability (Cannon and Hillebrandt, 1989 and Chiang et al, 2002), while sufficient investment enhances profit performance.

Drawing from the foregoing, the strategy to adopt for investing in physical capital to achieve a satisfactory level of financial performance becomes paramount. The objective of this paper, therefore, is to ascertain the extent to which hire purchase strategy of physical capital investment in construction companies affects financial performance. 


\section{Methodology}

This study adopts the survey research method. The reasons are because the survey method facilitates the collection of information from a sample of people using questionnaire; it is associated with quantitative findings and a few qualitative data and it is also designed to provide insights about causal explanations.

Construction companies quoted on the Nigerian Stock Exchange constitute the study population. From the 2006 Fact Book of the Nigerian Stock Exchange, six construction companies are listed. These six companies were sampled, representing $100 \%$ of the population. Quoted companies were used for easy identification of the study population and accessibility of respondents. They also have more permanent history of construction activities than unquoted ones and therefore, will provide more reliable information.

Data collected were mainly primary and secondary. Historical financial data were not used to avoid distortions arising from the heterogeneity of accounting methods and possible managerial manipulation associated with profitability measures (Li 2007, p.130). In addition, as a correlational study, it will not be appropriate to associate historical financial data with primary data. Information on the variables (hire purchase strategy - HPS and Financial performance - FP) were collected using questionnaire drawn on a five - point Likert type scale ranging from "never" to "always" for HPS and "fair" to "outstanding" for FP.

The questionnaire consisted of 6 (six) items, 3 (three) each for hire purchase strategy (HPS) and financial performance (FP) sub components (NP, ROA and ROE). Respondents were required to indicate their perceptions for each item on the scale (HP: no extent $=1$, very great extent $=5$; FP: fair $=1$, outstanding $=5$ ).

To explore the association between the dependent variables; net profit, return on assets and return on equity, which are the measures of financial performance; with the independent variable, hire purchase strategy; the following three hypotheses were conceived:

Ho1: There is no significant positive relationship between hire purchase strategy of physical capital investment and net profit of construction companies.

Ho2: There is no significant positive relationship between hire purchase strategy of physical capital investment and return on assets of construction companies.

$\mathrm{Ho}_{3}$ : There is no significant positive relationship between hire purchase strategy of physical capital investment and return on equity of construction companies.

\section{Data Presentation and Analysis}

Thirty sets of questionnaire were administered to the companies sampled. Table 1 in appendix 1 shows the numbers returned, rejected and accepted for analysis.

Twenty seven (27) sets of questionnaire representing a response rate of $90 \%$ were returned, four (4) representing $13 \%$ were rejected while twenty three (23) representing $77 \%$ were considered useful for analysis.

\subsection{Company Profiles.}

Profiles of organizations studied are important for proper comprehension of results of the survey and conclusions reached. Table 2 presents the companies' ages in business since being listed on the Nigerian Stock Exchange and shareholding structure (see appendix 1).

Table 2 indicates that $83.3 \%$ of the companies have been in business between twenty nine (29) to thirty four (34) years, while $16.67 \%$ was in business for seventeen (17) years. Similarly, the shareholding structure indicates that Nigerians have majority shares in five (5) companies ranging from $50.13 \%$ to $63.44 \%$ leaving $36.56 \%$ to $49.87 \%$ for foreigners, while in one (1) of the companies, foreign investment is $57.89 \%$ and Nigerian investment is $42.11 \%$.

The construction activities of the companies studied are shown in figure 1 of appendix 2.

From the respondents' views, more companies are in building (56.5\%) than others. $8.7 \%$ are into dredging, buildings, roads and bridges while $17.4 \%$ are engaged in the construction of roads and bridges.

\subsection{Profiles of Respondents}

As shown in figure 2 (see appendix 2), respondents sampled are those within management, senior and supervisory job cadre. Eight (8) representing $34.8 \%$ are at the management level, fourteen (14) which is $60.9 \%$ are senior personnel, 
while one (1) $4.3 \%$ is a supervisor. With respect to length of service of respondent individuals (see figure 3 of appendix 2), $17.4 \%$ have been in the employment of their companies for 5 years, $8.7 \%$ between $5-10$ years, $69.6 \%$ representing sixteen (16) out of the twenty three (23) respondents have spent over 15 years in the employment of their companies. The category of personnel sampled together with their length of service make information collected reliable.

\subsection{Reliability Analysis.}

The instruments used for data collection were subjected to reliability analysis using the Cronbach Alpha test. The objective is to ascertain if the data collected to establish the relationship between hire purchase strategy and measures of financial performance were reliable.

Table 3 in appendix 3 summarises the result of the analysis. From Table 3, the Cronbach Alpha coefficients are all above 0.60 Bagozzi in Cohen and Kaimenakis (2007, p. 251). This confirms that the measurement instruments are reliable and further indicates that all the variables involved in the study were effectively measured.

Explaining the descriptive statistics from the point of view of the mean score, application of hire purchase as an option for investing in physical capital is rated "some extent". From the measurement scale, this is a score of "2" which is below average. On the other hand, responses for financial performance (FP) measures are close to average, scoring between 2.3 to 2.7 respectively.

\subsection{Bivariate Data Analysis.}

This study aims at establishing relationship between hire purchase strategy of physical capital investment with financial performance measured in terms of net profit (NP), return on assets (ROA) and return on equity (ROE). In order to effectively comprehend this relationship, the scatter diagram was employed to measure their pattern while Pearson's product moment coefficient of correlation was applied to measure their strength. Figures 4, 5 and 6 in appendix 4 show the scatter diagrams between hire purchase strategy and profit after tax, return on assets and return on equity respectively.

The diagrams are sloped downwards from the upper left hand side to the lower right hand side indicating that the association between hire purchase strategy and net profit, return on assets and return on equity is negative. As the application of hire purchase strategy increases, financial performance of the companies in terms of NP, ROA and ROE decreases.

The correlation analyses in tables 4,5 and 6 further presents the strength of relationship between these variables (see appendix 5).

The analyses show that HPS is significantly negatively associated with all the measures of financial performance viz: NP, ROA and ROE. As indicated by their coefficients of correlation (NP $=-0.493$ table $4, \mathrm{ROE}=-0.430$ table 6 and $\mathrm{ROA}=-0.554$ table 5), the association is moderate with NP and ROE but strong with ROA.

From the foregoing, empirical results support $\mathrm{HO}_{1}, \mathrm{H}_{2}$ and $\mathrm{H}_{3}$. Judging from their coefficients of correlation, coefficients of determination are NP (0.243), ROA (0.307) and ROE (0.185). Statistically, hire purchase strategy of investment in physical capital accounts for decreases in net profit (NP), return on assets (ROA) and return on equity (ROE) by $24.3 \%, 30.7 \%$ and $18.5 \%$ respectively. There are, therefore, other factors that may impact on these dependent variables, for example, changes in technology.

\section{Discussion of Findings}

Findings from the demographics further confirm the abolition of the indigenisation policy in which equity investment is distributed as to $40 \%$ for foreigners and $60 \%$ for indigenes. With foreign investment rising up to $57.89 \%$ in one (1) of the companies studied, non - indigenous entrepreneurs are encouraged to fully manage and protect their capital investments in order to achieve optimum financial performance.

In addition, results of analyses do not present hire purchase option as an efficient physical capital investment strategy for quoted construction companies. The outcome of correlation analyses in which there exist statistically significant negative relationships between it and net profit, return on assets and return on equity (the measures of financial performance) confirms this assertion. This evidence is further corroborated by the result of the descriptive statistics where the mean score for its adoption as a physical capital investment strategy is 2.0145 (below average). Findings in this study are also in tandem with those of previous works. For example, Kehinde and Mosaku (2006, p. 639), in a survey eliciting responses for economic use of plant and equipment while studying the assets structure of building 
construction contractors in Nigeria, rated hire purchase 5.9\%, a score that indicates extreme poor application of hire purchase for physical capital acquisition.

These analytical results seem to be against expectations, especially, in a developing economy like Nigeria where capital accumulation to facilitate outright (cash) purchase of physical capital is difficult. Under such a situation, one would have expected the utilisation of hire purchase as a means of physical capital consumption. However, the deviation is because, companies studied are quoted and therefore, have access to funds from the investing public/institutions through public issue of shares.

Findings in this study may be generalised to other countries because the study population has a blend of foreign and local participation both in equity and management. Though, the number of companies studied may be considered small, similar studies in construction have used small number of companies/industries. For example, in China, Chan et al (2005, p. 115) and Ip and Hopewell (1987) studied eight (8) industries in construction, building and real estate respectively.

\section{Conclusions and Recommendations}

Hire purchase strategy of physical capital investment has a statistically significant negative association with net profit, return on assets and return on equity. Its application may not provide the quantum of physical capital needed to satisfy customers' expectations. Empirical results suggest that it accounts for $73.5 \%$ decreases in financial performance evaluated in terms of net profit $24.3 \%$, return on assets $30.7 \%$ and return on equity $18.5 \%$. The study is also significant as it provides literature on hire purchase, particularly in the context of Nigeria, an emerging economy.

Quoted construction companies were studied; future research should consider unquoted construction companies. In addition, data were drawn from an industry reliant on physical capital; it may be necessary to consider studies in industries less reliant on physical capital.

\section{References}

Achike, $\mathrm{O}$ (1985), Commercial Law in Nigeria, Enugu, Fourth Dimension Publishers.

Adesanye, M. O. and Oloyede, E. O. (1983), Business Law in Nigeria, Ibadan, Evans Brothers Limited.

Alexander, D and Britton, A. (1999), Financial Reporting, London, International Thompson Business Press.

Cannon, J. and Hillebrandt, P. M. (1989), Financial Strategy, in Hillebrandt,

P.M. and Cannon, J. (Eds), the Management of Construction Firms: Aspects of Theory, London, Macmillan, pp.57-73.

Chan, J. K. W.; Tam C. M. and Cheung, R. K. C. (2005). "Construction Firms at the Crossroads in Hong Kong: Going Insolvency or seeking Opportunity" Engineering, Construction and Architectural Management, vol. 12, №. 2, p. 115.

Cheah, C. Y. J., and Garvin, M. J. (2004), "An open framework for corporate strategy in construction", Engineering, construction and Architectural Journal, Vol. 11, №. 3, pp. 176 - 188.

Chiang, Y.H. Chan, A.P.C and Hui, C.M. E (2002), "Capital structure and profitability of properly and construction sectors in Hong Kong", Journal of Property Investment and Finance, Vol.20, No.6, pp. 434 - 53.

Cohen, S and Kaimenakis, N (2007), "Intellectual Capital and Corporate Performance in knowledge intensive SMES", The Learning Organization, vol. 14, No. 3 p. 251.

Day, D. A. and Benjamin, N. B. H. (1991). Construction Equipment Guide, New York, NY. Wiley,

Dyckman, T. R, Dukes, R. E and Davis, C. J.(1998),Intermediate Accounting, Massachusetts, McGraw -Hill.

Fry, Fred L; Stones, Charles, R. and Hattwick, Richard E. (1998), Business: An Integrated Framework, Boston, McGraw-Hill.

Harvey, M and Keer, F. (1978), Financial Accounting Theory, London. Prentice-hall International.

Hicks, H. G and Gullet, C. Ray (1981), Management, McGraw-Hill, New York.

Igweike, K. I. (1999), Nigerian Commercial Law - Hire Purchase, Ikeja, Malthouse Press Ltd.

Ip, Y.K. and Hopewell, M.H., (1987), "Corporate Financial Structure in Hon Kong”, Hong Kong Journal of Business Management, vol.v, pp. 21-31

Jaja, S. A. (2000), The Entrepreneurship Paradigm, Port Harcourt, Pearl Publishers.

Kehinde J. O. and Mosaku, T. O. (2006). "An Empirical Study of Assets Structure of Building Construction Contractors in Nigeria", Engineering, Construction and architectural Management, vol. 13 No. 6, pp. 634 - 639.

Libby, R; Libby, P. A and Short, D. G. (2001), Financial Accounting, New York. McGraw-hall Companies Inc.

Li, L., (2007), "Multinationality and Performance: A Synthetic Review and Future Research Agenda," International Journal of Management Reviews, vol. 9, issue 2, p. 130.

Okany, M. C. (1992), Nigerian Commercial Law, Onitsha, Africana-FEP Publishers Limited.

Pandey, I. M. (1979), Financial Management, New Delhi, Vikas Publishing House PVT Ltd.

Prasertrungruang, T and Hadikusumo, B. H. W. (2007), "Heavy Equipment Management Practices and Problems in Thai highway Contractors", Engineering, Construction and Architectural Management, vol. 14 No. 3, p. 228. 
Tatum, C. B. (1988), "Technology and Competitive Advantage in Civil Engineering", ASCE Journal of Professional issues in Engineering, vol. 114 No.3, pp. 256 -64.

The Hire Purchase Act, Cap H. 4, Laws of the Federation of Nigeria (LFN) 2004.

\section{Appendix 1.}

Table 1. Questionnaire Administration and Collection.

$\begin{array}{ccccc}\text { Companies } & \text { No. Administered } & \text { No. Returned } & \text { No. Rejected } & \text { No. Accepted } \\ 1 & 5 & 5 & 1 & 4 \\ 2 & 5 & 5 & - & 5 \\ 3 & 5 & 5 & - & 5 \\ 4 & 5 & 4 & - & 4 \\ 5 & 5 & 5 & 2 & 3 \\ 6 & 5 & 3 & 1 & 2 \\ \text { Total } & 30 & 27 & 4 & 23\end{array}$

Source: Survey data, Nov 2008.

Table 2. Ages in Business and Shareholding Structure.

\begin{tabular}{|l|l|l|l|l|l|}
\hline Company & \multicolumn{4}{|l|}{ Age in Business } & \multicolumn{4}{l|}{ Shareholding Structure } \\
\hline & Years & $\%$ & Nigerian & Foreign & Total \\
\hline 1 & 30 & 17.75 & 42.11 & 57.89 & 100 \\
\hline 2 & 34 & 20.12 & 63.44 & 36.56 & 100 \\
\hline 3 & 30 & 17.75 & 60.00 & 40.00 & 100 \\
\hline 4 & 29 & 17.16 & 55.24 & 44.76 & 100 \\
\hline 5 & 29 & 17.16 & 60.00 & 40.00 & 100 \\
\hline 6 & 17 & 10.06 & 50.13 & 49.87 & 100 \\
\hline Total & 169 & 100 & & & \\
\hline
\end{tabular}

Source: 2006 Stock Exchange Fact Book and 2002 - 2006 Annual Report \& Accounts.

\section{Appendix 2.}

Figure 1.Construction Activity.

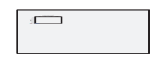

Source: Survey data, Nov 2008 and SPSS windows version15.0 
Figure 2. Job Cadre of Respondents.

Source: Survey data, Nov 2008 and SPSS windows version 15.0.

\section{Appendix 3.}

Figure 3. Length of Service of Respondents.

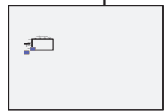

Source: Survey data, Nov 2008 and SPSS windows version 15.0

Table 3 Reliability Analysis

\begin{tabular}{|l|l|l|l|l|}
\hline & No. of Respondents & Mean & $\begin{array}{l}\text { Standard } \\
\text { Deviation }\end{array}$ & Cronbach's Alpha \\
\hline $\begin{array}{l}\text { Independent variable: } \\
\text { Hire purchase strategy (HPS) }\end{array}$ & 23 & 2.0145 & 1.057188 & 0.623 \\
\hline $\begin{array}{l}\text { Dependent variables: } \\
\text { Financial performance (FP) Measures: }\end{array}$ & 23 & & & \\
\hline Net Profit & 23 & 2.7391 & 1.13688 & 0.873 \\
\hline Return on Assets & 23 & 2.4783 & 1.16266 & 0.855 \\
\hline Return on Equity & 2.3919 & 1.19617 & 0.922 \\
\hline
\end{tabular}

Source: SPSS Windows Version 15.0. Scale: HPS: no extent $=1$, some extent $=2$, moderate extent 3 , great extent $=$ 4 , very great extent $=5$.

FP: Fair $=1$, good $=2$, very good $=3$, excellent $=4$, outstanding $=5$. 


\section{Appendix 4.}

Figure 4. Scatter diagram showing relationship between Hire purchase strategy and net profit.

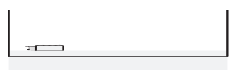

Figure 5. Scatter diagram showing relationship between Hire purchase strategy and return on assets.

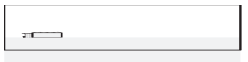

Figure 6. Scatter diagram showing relationship between Hire purchase strategy and return on equity.

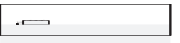

Source: Survey data, Nov 2008 and SPSS windows version 15.0

\section{Appendix 5.}

Table 4. Correlation analysis between hire purchase strategy and Net Profit.

\section{Correlations}

\begin{tabular}{|c|c|c|c|}
\hline & & Net Profit & $\begin{array}{l}\text { Hire purchase } \\
\text { strategy }\end{array}$ \\
\hline Net Profit & $\begin{array}{l}\text { Pearson Correlation } \\
\text { Sig. (2-tailed) } \\
\mathrm{N}\end{array}$ & $\begin{array}{r}1 \\
23\end{array}$ & $\begin{array}{r}-.493^{*} \\
.017 \\
23\end{array}$ \\
\hline $\begin{array}{l}\text { Hire purchase } \\
\text { strategy }\end{array}$ & $\begin{array}{l}\text { Pearson Correlation } \\
\text { Sig. (2-tailed) } \\
\mathrm{N}\end{array}$ & $\begin{array}{r}-.493^{*} \\
.017 \\
23\end{array}$ & $\begin{array}{r}1 \\
23\end{array}$ \\
\hline
\end{tabular}

*. Correlation is significant at the $\mathbf{0 . 0 5}$ level (2-tailed). 
Table 5. Correlation analysis between hire purchase strategy and Return on assets.

Correlations

\begin{tabular}{|ll|r|r|}
\hline & $\begin{array}{c}\text { Hire purchase } \\
\text { strategy }\end{array}$ & $\begin{array}{c}\text { Return on } \\
\text { Assets }\end{array}$ \\
\hline Hire purchase & Pearson Correlation & 1 & $-.554^{* *}$ \\
strategy & Sig. (2-tailed) & & .006 \\
& $\mathrm{~N}$ & 23 & 23 \\
\hline Return on Assets & Pearson Correlation & $-.554^{* *}$ & 1 \\
& Sig. (2-tailed) & .006 & \\
& $\mathrm{~N}$ & 23 & 23 \\
\hline
\end{tabular}

${ }^{* *}$. Correlation is significant at the 0.01 level (2-tailed).

Table 6. Correlation analysis between hire purchase strategy and Return on equity.

\section{Correlations}

\begin{tabular}{|ll|r|r|}
\hline & & $\begin{array}{c}\text { Hire purchase } \\
\text { strategy }\end{array}$ & $\begin{array}{c}\text { Return on } \\
\text { Equity }\end{array}$ \\
\hline Hire purchase s trategy & Pearson Correlation & 1 & $-.430^{*}$ \\
& Sig. (2-tailed) & & .041 \\
& $\mathrm{~N}$ & 23 & 23 \\
\hline Return on Equity & Pearson Correlation & $-.430^{*}$ & 1 \\
& Sig. (2-tailed) & .041 & \\
& $\mathrm{~N}$ & 23 & 23 \\
\hline
\end{tabular}

*. Correlation is significant at the 0.05 level (2-tailed).

Source: Survey data, Nov 2008 and SPSS windows version 15.0 